\title{
Optical, Structural and Electrical Properties of Cu Doped CdS Thin Films Fabricated by SILAR Method
}

\author{
D. Pradhabhan ${ }^{* 1} \&$ Dr. A. Sakthivelu ${ }^{2}$ \\ ${ }^{1,2}$ PG \& Research Department of Physics, \\ Periyar E.V.R College, Trichy, Tamilnadu.
}

\begin{abstract}
Cu doped CdS nano crystalline thin films were deposited using one of the simple Successive Ionic Layer Adsorption and Reaction (SILAR) method. The result and impact of $\mathrm{Cu}$ doping concentration of 3,6 and $9 \mathrm{Mol} \%$ on the optical, structural, morphological and electrical properties of $\mathrm{Cu}$ doped $\mathrm{CdS}$ films were studied. XRD studies exhibited that the $\mathrm{Cu}$ doped $\mathrm{CdS}$ thin were polycrystalline with cubic phase crystal structure. FESEM results show that the surface morphology of the prepared films changes with $\mathrm{Cu}$ doping concentration. A blue shift in the optical band gap was found in the UV visible spectroscopy. Hall measurements clearly indicate the result and impact of $\mathrm{Cu}$ doping concentration on electrical resistivity and conductivity and it shows comparatively high electrical conductivity at $9 \mathrm{Mol} \%$ of $\mathrm{Cu}$ doping concentration.
\end{abstract}

Keywords: Copper doped Cadmium Sulphide, SILAR, Thin films, $U V \& X R D$

\section{INTRODUCTION:}

Cadmium sulphide (CdS) is an n-type semiconducting material that has been used in several applications, including low cost solar cells, light emitting diodes, photo resistance sensors, nonlinear optical devices and optical waveguides [1-4]. Different deposition techniques have been used to fabricate the cadmium sulphide thin films, such as chemical bath deposition, vacuum evaporation, spray Pyrolysis, sputtering, electro deposition [5] and Successive Ionic Layer Adsorption and Reaction (SILAR) [6,7] method. Among all the deposition methods, SILAR method is an important, cost effective and simple technique for the fabrication of multi-component thin films. The $\mathrm{Cu}$ doped $\mathrm{CdS}$ thin films have many possible applications, such as high efficiency photovoltaic cells and light emitters because the thin films of $\mathrm{Cu}$ doped $\mathrm{CdS}$ thin films are known to be extremely sensitive to absorb the electromagnetic radiation that on coverage to any type of radiation is capable of stimulating electron-hole pairs and can display a notable structural changes. Moreover, the doping of $\mathrm{Cu}$ modifies the band gap energy of $\mathrm{CdS}$ and also enhances its photoelectrical properties. Aim of the present work is to study the result of doping $\mathrm{cu}$ on the structural, electrical and optical properties of the $\mathrm{CdS}$ thin films synthesised by SILAR method.

\section{EXPERIMENTAL PROCEDURE}

All the chemicals used to prepare the $\mathrm{Cu}$ doped $\mathrm{CdS}$ thin films were of analytical grade and all the solutions were prepared in the millipore water. To deposit the $\mathrm{Cu}$ doped CdS thin films, cationic precursor $(0.1 \mathrm{M})$ cadmium acetate $(50 \mathrm{ml})$ and $(0.003 \mathrm{M})$ Copper Sulphate were taken in a beaker and the anionic precursor $(0.1 \mathrm{M})$ Thiourea $(50 \mathrm{ml})$ was taken in a separate beaker. For the deposition of $\mathrm{Cu}$ doped CdS thin film, well cleaned glass substrate was immersed into the cationic precursor for $40 \mathrm{sec}$ for the adsorption of $\mathrm{Cd}^{2+}$ and $\mathrm{Cu}^{2+}$ ions on the surface of the glass substrate, and then the substrate was dipped into the double distilled de-ionized water for $10 \mathrm{sec}$ to avoid precipitation and also to remove the weakly bounded cations. The substrate was then immersed into the anionic precursor bath for $40 \mathrm{sec}$ for reaction of $\mathrm{S}^{2-}$ ions with $\mathrm{Cu}^{2+}$ and $\mathrm{Cd}^{2+}$ ions on the substrate. This process was carried out at $\sim 75^{\circ} \mathrm{C}$ temperature. Successive dipping cycles repeated up to 75 times, to get the well adherent and homogeneous $\mathrm{Cu}$ doped $\mathrm{CdS}$ thin films [8]. Then the same procedures were carried out for 0.006 and $0.009 \mathrm{~mol}$ of $\mathrm{Cu}$. Doping of $\mathrm{Cu}$ is carried out the following molar ratio and they are 3, 6 and 9 respectively. The samples were annealed at $200^{\circ} \mathrm{C}$ for 1 hour in atmospheric air. Phase identification and crystalline properties of the films were studied by XPERT-PRO X-ray powder diffractometer with $\mathrm{CuK} \alpha$ radiation $(\lambda=1.5418 \AA)$. Scanning electron microscopy FE-SEM $6701 \mathrm{~F}$ used to study the surface Morphology and to illustrate the formation of crystallites on the film surface. UV-VIS spectrophotometric measurements were performed using a Unico UV2102PCS spectrophotometer at room temperature. The electrical parameters were measured using Hall measurements setup (ECOPIA-HMS 3000) at room temperature with the permanent magnet of 0.57 Tesla.

\section{RESULT AND DISCUSSION}

\subsection{Structural Analysis}




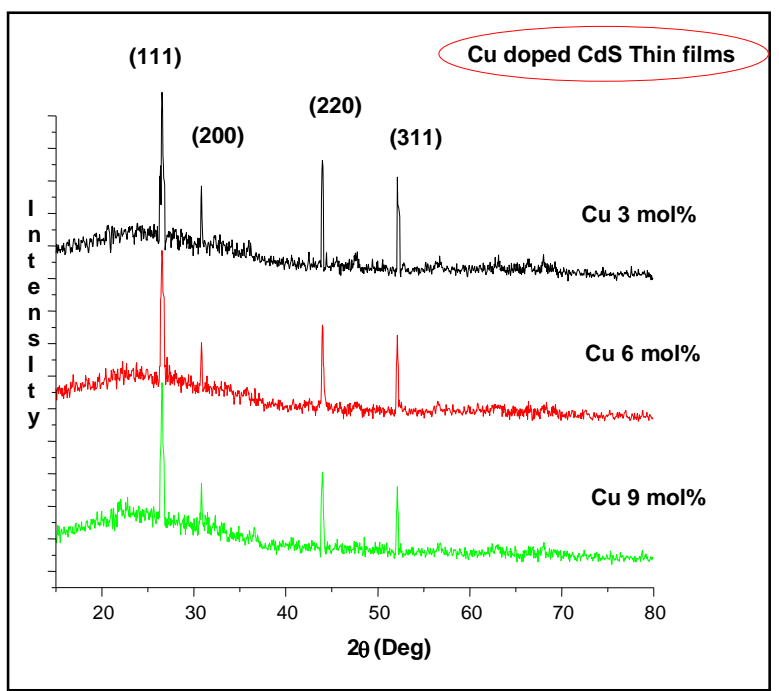

Fig.1-XRD patterns of $\mathrm{Cu}$ doped $\mathrm{CdS}$ thin films

The crystalline nature of $\mathrm{Cu}$ doped $\mathrm{CdS}$ films was examined by X-ray diffraction spectra obtained by grazing incidence X-ray diffraction. Fig.(1) shows the XRD spectra of the SILAR deposited $\mathrm{Cu}$ doped $\mathrm{CdS}$ films, which exhibits the X-ray diffraction spectra of CdS. The diffraction pattern exhibits the entire characteristic peaks of the cubic (zincblende) phase, which is good agreement with the reported standard values (ICDD No. 10-0454). In the diffraction pattern, (111) reflection was the prominent peak than the other intensity peaks. Intensity of the (200), (220) and (311) diffraction peaks were decreased with increasing the $\mathrm{Cu}$ doping concentration, which indicates that excessive doping level of $\mathrm{Cu}$ deteriorates the crystallinity in the prepared films, which might be due to the improvement of stress caused by the smaller ionic radius of $\mathrm{Cu}^{2+}$ compared with $\mathrm{Cd}^{2+}$ ions. In order to determine lattice parameter of the prepared thin films, JANA2006 code was used in the Le-Bail mode. The calculated lattice parameters of $\mathrm{Cu}$ doped $\mathrm{CdS}$ thin films were tabulated in Table.1. It can also observed that, for the increase in the $\mathrm{Cu}$ doping concentration from $3 \mathrm{Mol} \%$ to 9 Mol\% lattice constant (a) decreased linearly from 5.9309 to $5.8760 \AA$. $\mathrm{Tl}$ a ght change in lattice parameter 'a' of $\mathrm{Cu}$ doped $\mathrm{CdS}$ arrm film, prove that the $\mathrm{Cu}$ ions were incorporated successfully into the $\mathrm{CdS}$ lattice. This slight drop in the intensity peaks of the deposited thin films are attributed to the reduction in the crystallinity of the thin films. The well known Scherer formula [9] given in equation (1) used to determine the crystallite size of the SILAR deposited $\mathrm{Cu}$ doped $\mathrm{CdS}$ thin films and the average lattice strain has been calculated using Stokes Wilson equation [10] given in equation (2), The FWHM values of the prepared films were determined from their highest intensity peak broadening by pseudo-voigt peak fitting.

Crystallite size $D_{\text {ave }}=0 \cdot 94 \lambda / \beta \cos \theta-----(1)$

Micro Strain $\varepsilon=\beta / 4 \tan \theta-----(2)$

Where $D_{\text {ave }}$ is the mean crystallite size, $\varepsilon$ is the average micro strain $(\Delta d / d), \beta$ the full width at half maximum of the diffraction line, $\theta$ angle of diffraction, and $\lambda$ the wavelength of the X-ray radiation. The minimum crystallite size of $\sim 14.36 \mathrm{~nm}$ is found for $9 \mathrm{Mol} \%$ of $\mathrm{Cu}$ doped thin film and the maximum crystallite size of $\sim 18.87$ $\mathrm{nm}$ is found for $3 \mathrm{Mol} \%$ of $\mathrm{Cu}$ doped thin film which is shown in Table.01.

\begin{tabular}{|c|c|c|c|}
\hline $\begin{array}{c}\text { Cu doping } \\
\text { concentration } \\
\text { (Mol. \%) }\end{array}$ & $\begin{array}{c}\text { Crystallite size, } \\
\mathrm{D}(\mathrm{nm})\end{array}$ & ' $\mathrm{a}$ '( $\mathrm{A})$ & $\begin{array}{l}\text { Micro Strain- } \\
\epsilon\end{array}$ \\
\hline 3 & 18.87 & 5.9309 & $3.13 \times 10^{-3}$ \\
\hline 6 & 16.69 & 5.9100 & $3.51 \times 10^{-3}$ \\
\hline 9 & 14.36 & 5.8760 & $3.72 \times 10^{-3}$ \\
\hline
\end{tabular}

Table .1 - Structural parameters of $\mathrm{Cu}$ - doped $\mathrm{CdS}$ thin films

\subsection{Surface Morphology and EDAX by FESEM Analysis}

Surface Morphology and EDAX by FESEM Analysis The FESEM micrographs of SILAR deposited $\mathrm{Cu}$ doped $\mathrm{CdS}$ thin films for the various $\mathrm{Mol} \%$ of $\mathrm{Cu}(3 \mathrm{Mol} \%, 6$ Mol \% and $9 \mathrm{Mol} \%$ ) on well cleaned glass substrates are shown in Fig. 2 (a), (c) and (e) respectively. It is observed that the surface morphology of the prepared thin films are strongly depends on the concentration of the $\mathrm{Cu}$ dopant. The grains almost cover the surface of substrate uniformly. However, $\mathrm{Cu}$ doped $\mathrm{CdS}$ thin film shows particles with partially spherical like shape in $3 \mathrm{~mol} \%$ of $\mathrm{Cu}$ doping concentration. Fig. 2(c) shows particles on the surface of substrate were seemed to be agglomerated with better surface coverage in $6 \mathrm{~mol} \%$ of $\mathrm{Cu}$ doping concentration. The surface of the $9 \mathrm{Mol} \%$ of $\mathrm{Cu}$ doped CdS film shows nearly completes substrate coverage and decrease in grain size.

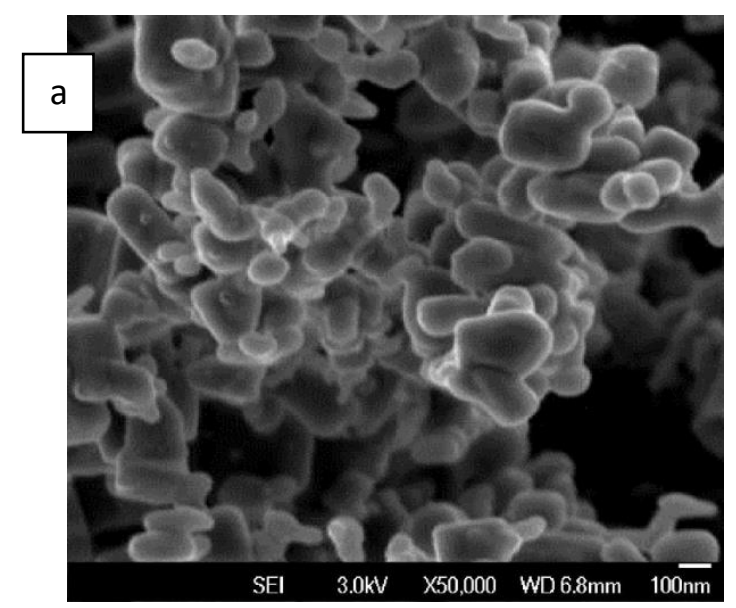

Fig.2(a). Surface morphology of $\mathrm{Cu}(3 \mathrm{~mol} \%)$ doped $\mathrm{CdS}$ thin films 


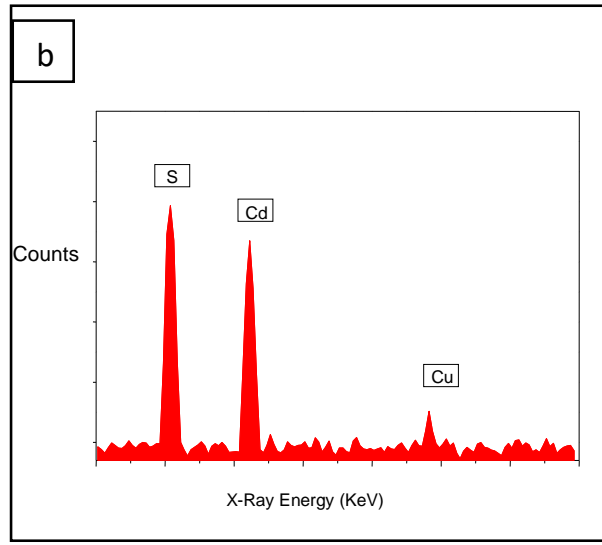

Fig.2(b). EDAX analysis of $\mathrm{Cu}(3 \mathrm{~mol} \%)$ doped CdS thin films

The prepared samples, the grain size decreases and grain orientation occur randomly when $\mathrm{Cu}$ incorporated with $\mathrm{CdS}$ lattice. The surface of $\mathrm{Cu}$ doped $\mathrm{CdS}$ thin films are seems to be formed by the stacking with self-aligned nanoparticles. The incorporation of $\mathrm{Cu}$ in the $\mathrm{CdS}$ films was verified by the EDAX result. Figure 2 (b), (d) \& (f) shows the energy-dispersive $\mathrm{X}$-ray analysis of $\mathrm{Cu}$ doped CdS film for $3 \mathrm{Mol} \%, 6 \mathrm{Mol} \%$ and $9 \mathrm{Mol} \%$ respectively. The EDAX result evidently reveals the presence of $\mathrm{Cd}, \mathrm{S}$ and incorporation of $\mathrm{Cu}$ in the deposited thin films.

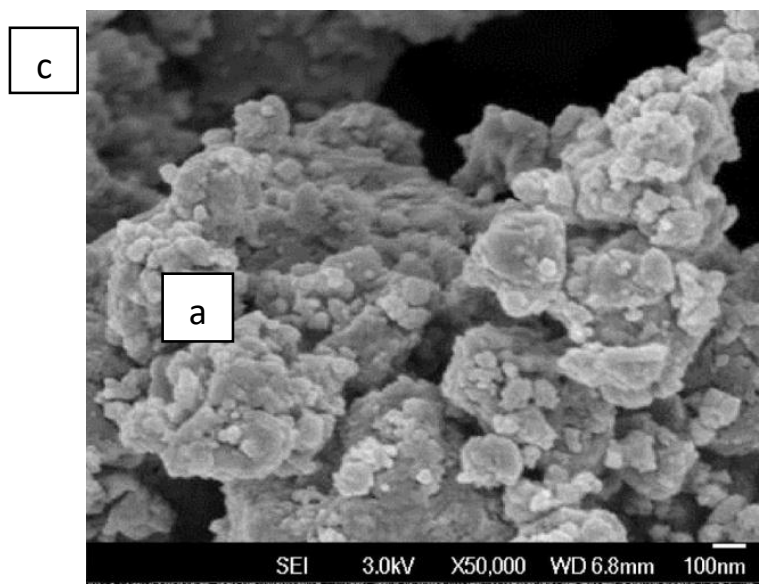

Fig.2(c). Surface morphology of $\mathrm{Cu}(6 \mathrm{~mol} \%)$ doped $\mathrm{CdS}$ thin films

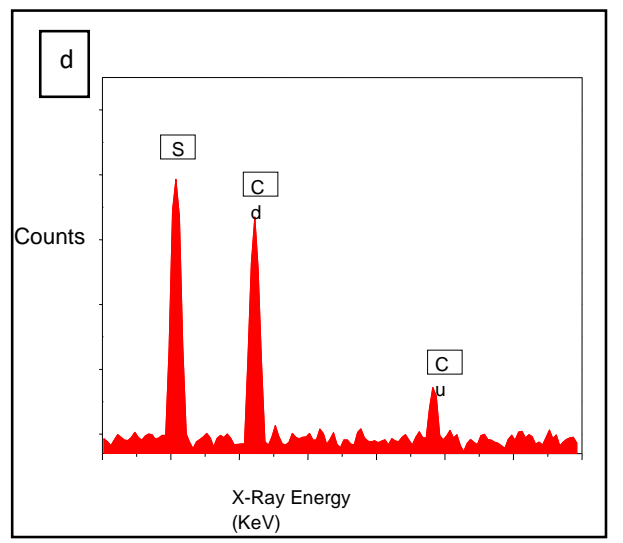

Fig.2(f). EDAX analysis of $\mathrm{Cu}(6 \mathrm{~mol} \%)$ doped CdS thin films

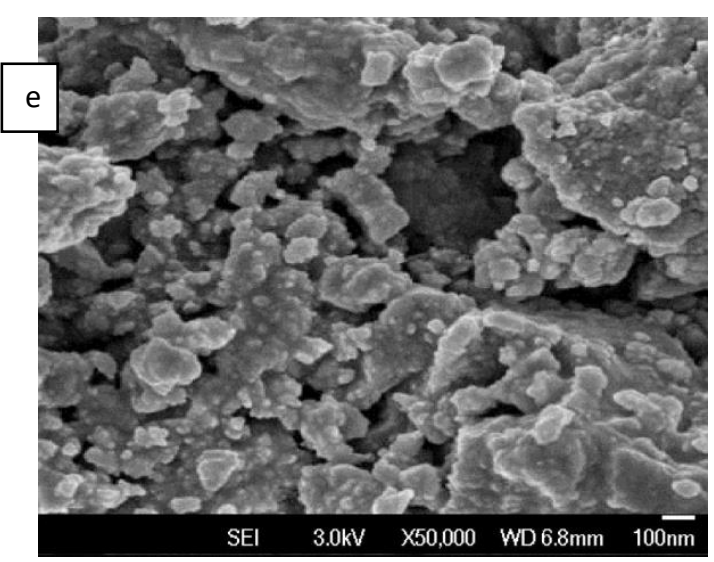

Fig.2(e). Surface morphology of $\mathrm{Cu}(9 \mathrm{~mol} \%)$ doped $\mathrm{CdS}$ thin films

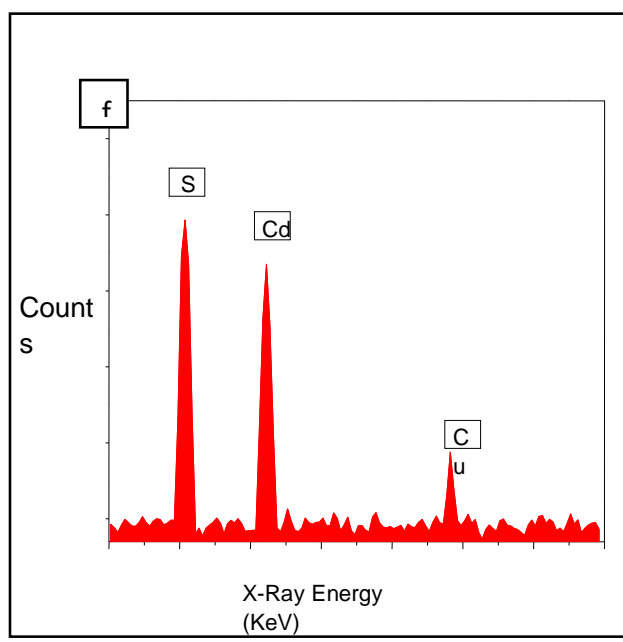

Fig.2(f). EDAX analysis of $\mathrm{Cu}(9 \mathrm{~mol} \%)$ doped CdS thin films

\subsection{Optical studies}

The transmittance spectrum in the wavelength range of 300 to $1100 \mathrm{~nm}$ for $\mathrm{Cu}$ doped $\mathrm{CdS}$ thin films are shown in Fig. 3(a). It shows that the transmittance of $6 \mathrm{~mol} \%$ and 9 mol\% of $\mathrm{Cu}$ doped thin films is lower than that of $3 \mathrm{Mol} \%$ of $\mathrm{Cu}$ doped films. This reduction in transmittance at higher $\mathrm{Cu}$ doping concentrations may be due to the increase in the scattering of photons caused by crystal defects as well as its irregular surface morphology.

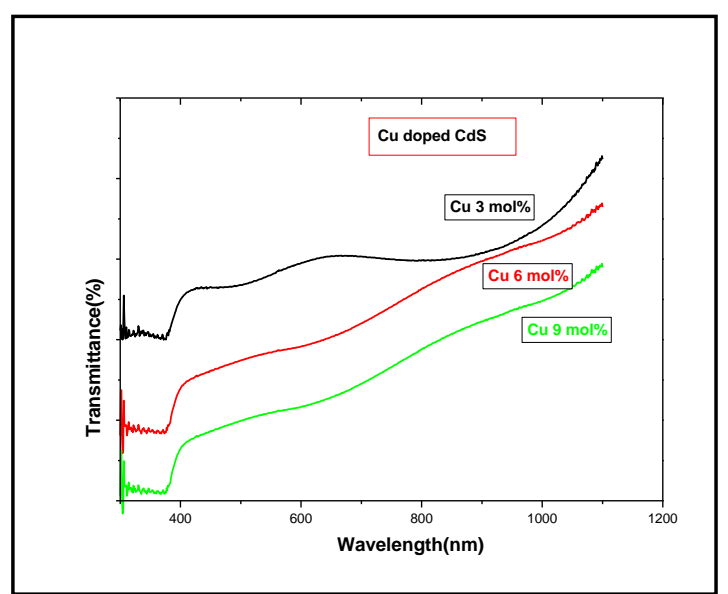

Fig.3 (a) - Transmittance graph of $\mathrm{Cu}$ doped CdS films 


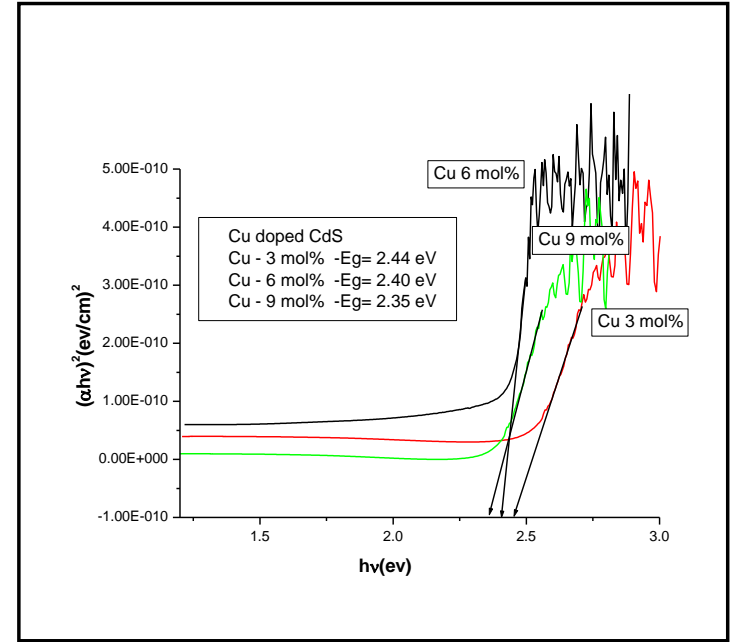

Fig. 3 (b) - Band gap of $\mathrm{Cu}$ doped CdS thin films

The optical band gap Eg can be calculated by plotting (hv) versus $(\alpha \mathrm{h} v)^{2}$ based on the relation $\mathrm{h}=\mathrm{A}(\mathrm{h}-\mathrm{Eg})^{\mathrm{n} / 2}$ where $\alpha$ is the absorption coefficient, $\mathrm{A}$ is a constant and $\mathrm{n}$ is the exponent depending on quantum selection rule for a particular material[11]. The calculated band gap value with respect to $\mathrm{Cu}$ doping concentration is plotted in fig. 3(b), which clearly indicates the considerable decrease in band gap value with increase in $\mathrm{Cu}$ doping concentration. The optical band gap for $3 \mathrm{Mol} \% \mathrm{Cu}$ doped $\mathrm{CdS}$ film is 2.44 $\mathrm{eV}$ which is higher than the remaining two samples. For 6 $\mathrm{Mol} \% \mathrm{Cu}$ doped CdS film the band gap is $2.40 \mathrm{eV}$ and for $9 \mathrm{Mol} \% \mathrm{Cu}$ doped $\mathrm{CdS}$ film $2.35 \mathrm{eV}$. This reduction in band gap value with respect in increase in $\mathrm{Cu}$ doping concentration clearly indicates the effect of $\mathrm{Cu}$ doping level on the CdS thin films. Fig. 3(b) clearly exhibit a blue shift in the higher $\mathrm{Cu}$ doping concentration, indicating the narrowing of the optical band gap value. This narrowing of $\mathrm{Eg}$ value for $\mathrm{Cu}$-doped $\mathrm{CdS}$ thin films suggests the successful incorporation of $\mathrm{Cu}$ in $\mathrm{CdS}$ structure.

\subsection{Electrical Studies}

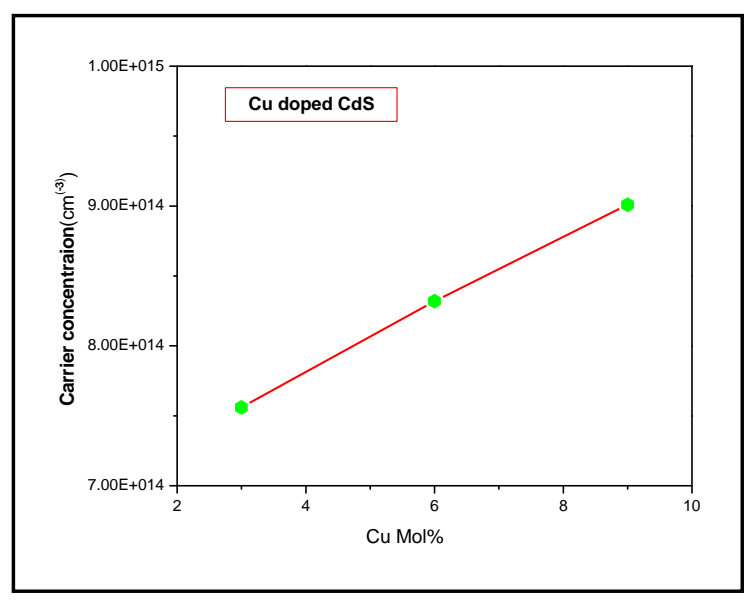

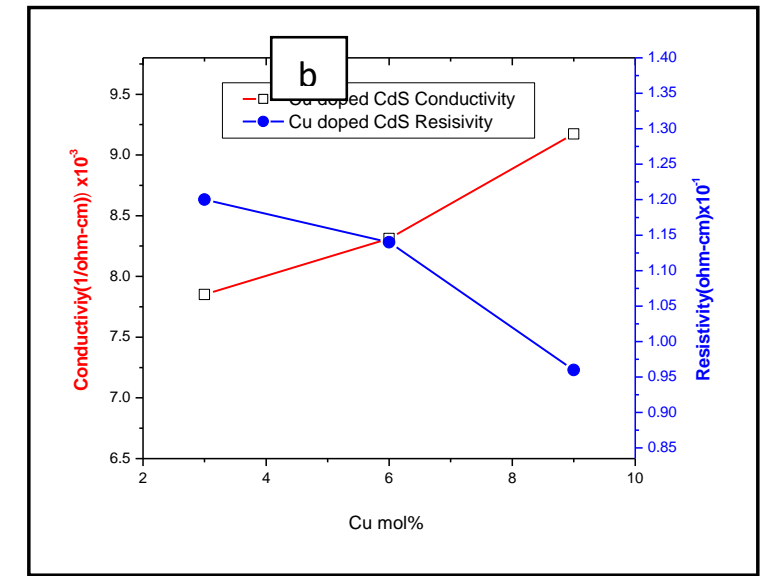

Fig.4. (a) \& (b) shows variation of Resistivity, Conductivity \& carrier concentration of $\mathrm{Cu}$ doped $\mathrm{CdS}$ films

Table.02-Resistivity, Conductivity \& carrier concentration of $\mathrm{Cu}$ doped CdS films

\begin{tabular}{|l|l|l|l|l|}
\hline Film & Resistivity & Conductivity & $\begin{array}{l}\text { Hall } \\
\text { Carrier } \\
\text { concentrati } \\
\text { on } \\
\left(\mathbf{c m}^{-3}\right)\end{array}$ & $\begin{array}{l}\text { Coefficie } \\
\text { nt }\end{array}$ \\
$\left(\mathbf{c m}^{3} / \mathbf{C}\right)$ \\
\hline $\begin{array}{l}3 \mathrm{~mol} \% \\
\text { of } \mathrm{Cu}\end{array}$ & $6.104 \times 10^{2}$ & $2.089 \times 10^{-03}$ & $6.501 \times 10^{16}$ & $\begin{array}{l}4.159 \\
\times 10^{7}\end{array}$ \\
\hline $\begin{array}{l}6 \mathrm{~mol} \% \\
\text { of } \mathrm{Cu}\end{array}$ & $5.322 \times 10^{2}$ & $3.110 \times 10^{-03}$ & $9.518 \times 10^{16}$ & $\begin{array}{l}1.774 \\
\times 10^{6}\end{array}$ \\
\hline $\begin{array}{l}9 \mathrm{~mol} \% \\
\text { of } \mathrm{Cu}\end{array}$ & $4.787 \times 10^{2}$ & $4.154 \times 10^{-03}$ & $1.950 \times 10^{17}$ & $\begin{array}{l}7.301 \\
\times 10^{5}\end{array}$ \\
\hline
\end{tabular}

The various Hall parameters such as conductivity, carrier concentrations $(n)$, resistivity and hall coefficient have been calculated and tabulated in Table. 2 . The variation of the carrier concentration with $\mathrm{Cu}$ doping content is shown in Fig.4 (a). It is revealed that $\mathrm{Cu}$ content is a factor which affects the electrical properties of the CdS thin film. It can be observed from Fig.4 (b) that the thin film shows comparatively the highest conductivity and the lowest resistivity at a $\mathrm{Cu}$ doping concentration of $9 \mathrm{Mol} \%$.The increase in the electrical conductivity is due to the occurrence of huge number of free charge carriers introduced by $\mathrm{Cu}$ dopant. It can be explained as follows: when $\mathrm{Cu}$ is incorporated in to the $\mathrm{CdS}$ lattice, $\mathrm{Cu}^{2+}$ replaces $\mathrm{Cd}^{2+}$ ion in the $\mathrm{CdS}$ crystal structure resulting in four more free electrons that contribute to the electric conduction. So, the enhancing electrical conductivity is due to the presence of large numbers of free carriers introduced by $\mathrm{Cu}$ dopant. The highest value of carrier concentration obtained in the present study is $1.950 \times 10^{17}$ $\mathrm{cm}^{-3}$ and it is observed at $9 \mathrm{Mol} \%$ of $\mathrm{Cu}$ doped $\mathrm{CdS}$ films. 


\section{CONCLUSIONS}

SILAR deposition method is used to prepare the polycrystalline $\mathrm{Cu}$ doped $\mathrm{CdS}$ thin films on glass substrates. The effects of $\mathrm{Cu}$ doping concentration on structural, optical, surface morphological and electrical characterizations of CdS films were studied. The XRD results clearly show that $\mathrm{Cu}$ doped $\mathrm{CdS}$ films have cubic structure. When the doping concentration is $3 \mathrm{Mol} \%$, the intensity of (111) peak is stronger than that of other intensity peaks. This literature reveals that the decrease in the XRD intensity peaks of the deposited thin films are attributed to the reduction in the crystallinity of the thin films and also it indicates that, $\mathrm{Cu}$ ions were successfully incorporated into the CdS lattice. The FESEM images revealed that, up on increasing the $\mathrm{Cu}$ doping content, the surface morphology of the films is improved and grains are uniformly distributed throughout the surface. Optical studies reveals that, the optical band gap $\mathrm{Eg}$ of $\mathrm{Cu}$ doped $\mathrm{CdS}$ thin films decrease with increasing $\mathrm{Cu}$ doping concentration in the samples. Hence, the decrease in the optical band gap from 2.44 to $2.35 \mathrm{eV}$ is observed for increasing the $\mathrm{Cu}$ doping concentration from 6 to $9 \mathrm{~mol} \%$ respectively. From the electrical studies, it is observed that the variation in electrical resistivity might be directly attributed to the effect of $\mathrm{Cu}$ ion incorporation into the $\mathrm{CdS}$ lattice. At $9 \mathrm{Mol} \%$ of $\mathrm{Cu}$ doping, the thin films exhibit the highest electrical conductivity and lower resistivity. The structural, optical and electrical characterization studies of
$\mathrm{Cu}$ doped $\mathrm{CdS}$ thin films clearly indicate the successful incorporation of $\mathrm{Cu}$ into $\mathrm{CdS}$.

\section{REFERENCES}

[1] Kashiwaba, Y., Sato, J. and Abe, T., Appl. Surface Science, 212213, pp 162-165(2003).

[2] Bacaksiz, E., Novruzov, V., Karel, H., Yanmaz, E.,Altunbas, M., Kopya, A.I. , J. Phys. D: Appl. Phys., 34, pp 3109-3112 (2001).

[3] Ullrich, B., Bagnall, D.M., Sakai, H. And Segawa, Y, Journal of Luminescence, 87-89, pp 1162-1164 (2000).

[4] Senthil, K., Mangalarj, D., Narayandass, S.K., Applied Surface Science, $169-170, \mathrm{pp}$

[5] 476-479 (2001).

[6] Ulrich, B., Tomm, J.W., Dushkina, N.M., Tomm, Y.,Sakai, H. and Segawa, Y., Solid

[7] State Communications, 116, pp 33-35 (2000)

[8] R.Radha, A.Sakthivelu, D.Pradhabhan, C.Ravichandiran, S.Murugesan, E.Mohandas and Geethadhevi, International Journal of ChemTech Research, Vol.6, No.6, pp 3374 3377(2014)

[9] R. Radha, A. Sakthivelu, D.Pradhabhan, C. Ravichandiran, S. Murugesan, \& E. Mohandas, Journal of Scientific Research in Physical \& Mathematical Science Volume (2) Issue (9) Year (2015)ISSN : 2349-7149

[10] D. Pradhabhan, Dr. A. Sakthivelu, International Journal of Advanced Trends in

[11] Engineering and Technology (IJATET), Volume 2, Issue 2, 2017

[12] S Tewari and A Bhattacharjee, Pramana - J. Phys. 76, 153 (2011)

[13] P Shrestha, R Ghimire, J J Nakarmi, Young Sung Kim, S Shrestha, C Y Park and J H Boo, Bull. Korean Chem. Soc. 31, 112 (2010)

[14] Muhammad Nafees, Wasim Liaqut, Salamat Ali, Muhammad Ahsan Shafique Appl Nanosci (2013) 3:49-55 